\title{
A new genus and two new species of saccamminid foraminiferans (Protista, Rhizaria) from the deep Southern Ocean*
}

\author{
TOMAS CEDHAGEN ${ }^{1 \#}$, ANDREW J. GOODAY ${ }^{2} \& \mathrm{JAN}$ PAWLOWSKI ${ }^{3}$ \\ ${ }^{\prime}$ Department of Marine Ecology, Institute of Biological Sciences, University of Aarhus, Finlandsgade 14, DK-8200 Aarhus N, \\ Denmark \\ ${ }^{2}$ National Oceanography Centre, Southampton, Empress Dock, European Way, Southampton SO14 3ZH, UK. \\ ${ }^{3}$ Department of Zoology and Animal Biology, University of Geneva, Sciences III, 30, Quai Ernest Ansermet, CH 1211 Genève 4, \\ Switzerland \\ \# Corresponding author: cedhagen@biology.au.dk
}

* In: Brökeland, W. \& George, K.H. (eds) (2009) Deep-sea taxonomy - a contribution to our knowledge of biodiversity. Zootaxa, 2096, 1-488.

\begin{abstract}
We describe two new species of spherical single-chambered ('saccamminid') foraminifera from the bathyal and abyssal Weddell Sea (Southern Ocean), collected in epibenthic sledge and Agassiz trawl samples obtained during the 2005 ANDEEP III campaign. Both are assigned to Leptammina gen. nov. The new genus is similar in overall test morphology to Saccammina Carpenter, 1869; it is distinguished mainly by its test wall, which is delicate, flexible and composed of fine mineral grains, rather than being rigid and coarsely agglutinated. In Leptammina grisea gen. et sp. nov., the test wall is relatively thick, grayish with a violet tinge and a dull surface; the cytoplasm is dark greenish. In Leptammina flavofusca gen. et sp. nov., the test is yellowish brown, with a very finely, almost transluscent agglutinated wall; the cytoplasm is pale yellowish. Both species have prominent circular apertures. Maximum likelihood phylogenetic analysis of SSU rRNA gene data showed that both species group together with an undescribed shallow-water Antarctic species ("silver saccamminid") in a very strongly supported clade (100\%). Leptammina grisea gen. et sp. nov. is a relatively uncommon species (29 specimens from 3 stations), found at 1580-4822 m depth in the central and north-western Weddell Sea; Leptammina flavofusca gen. et sp. nov. is common (398 specimens from 4 stations) at depths of 3138-4795 $\mathrm{m}$ in the central Weddell Sea and off Kapp Norvegia. Both species are presently known only from ANDEEP III samples.
\end{abstract}

Keywords: Foraminifera, Weddell Sea, Antarctica, Leptammina, Taxonomy, Deep Sea, ANDEEP

\section{Introduction}

Monothalamous (single-chambered) foraminiferans are a common and widespread component of benthic marine faunas and sometimes dominate the meiofaunal size fraction (Gooday 2002). However, this group is regarded as difficult to work with, and therefore often overlooked or neglected, because of paucity of clear morphological characters of the test or cell content. As a result, many species remain undescribed. Foraminiferans have been investigated in Antarctic waters for more that a hundred years (see Cornelius \& Gooday 2004 for references), but few monothalamous species have been described. A large number of undescribed single-chambered taxa were collected during the ANDEEP II and III expeditions to the Weddell Sea and adjacent areas (Pawlowski et al. 2004; Gooday et al. 2006). Two species, Conqueria laevis and Bathyallogromia weddellensis present in ANDEEP II samples were recently described by Gooday \& Pawlowski (2004) and Gooday et al. (2004a), respectively. A third species, Vellaria zuccellii, was established 
by Sabbatini et al. (2004) based on samples collected in Terra Nova Bay in the Ross Sea. Komokiaceans collected during the ANDEEP III expedition are treated by Gooday et al. (2007a,b). Here, we focus on two new species of monothalamous foraminiferans collected during the ANDEEP III campaign from the Weddell Sea. Although their superficial appearance is rather different, molecular analyses reveal that the two new species are closely related. We therefore place them in the same genus and establish a new genus in order to accommodate them.

General descriptions of the biogeography of Southern Ocean foraminiferans and metazoans are provided by Mikhalevitch (2004), Brandt et al. (2007) and Pawlowski et al. (2007).

\section{Material and Methods}

Sampling and stations: the material was collected on the Kapp Norvegia continental slope, the Weddell Sea Abyssal Plain, and to the east of the tip of the Antarctic Peninsula during RV Polarstern Cruise ANTXXII-3 (ANDEEP III, 21 January to 6 April 2005), using either an Agassiz trawl or an epibenthic sledge (Gooday et al. 2006). Station positions are given in Table 1. See Gooday et al. (2006) for a detailed description of the shipboard sampling, sieving, sorting, photographing, and fixing procedures used.

TABLE 1. Sampling station positions. Sampling gears: EBS $=$ Epibenthic sledge, $G K G=$ giant box corer (Großkastengreifer), AT = Agassiz trawl.

\begin{tabular}{|c|c|c|c|c|}
\hline \multirow{2}{*}{$\begin{array}{l}\text { Station and } \\
\text { deployment }\end{array}$} & \multicolumn{2}{|c|}{ Position } & \multirow[t]{2}{*}{ Depth (m) } & \multirow[t]{2}{*}{ Gear } \\
\hline & ${ }^{\circ} \mathrm{S}$ & ${ }^{\circ} \mathbf{E}$ & & \\
\hline \multicolumn{5}{|c|}{ Kapp Norvegia continental slope transect } \\
\hline 80\#9 & $70^{\circ} 39.23^{\prime}$ & $14^{\circ} 43.59^{\prime}$ & $3102-3136$ & EBS \\
\hline 81\#9 & $70^{\circ} 31.49^{\prime}$ & $14^{\circ} 34.89^{\prime}$ & 4526 & GKG \\
\hline \multicolumn{5}{|c|}{ Weddell Abyssal Plain transect } \\
\hline $102 \# 11$ & $65^{\circ} 31.29^{\prime}$ & $36^{\circ} 36.40^{\prime}$ & $4794-4805$ & AT \\
\hline $102 \# 13$ & $65^{\circ} 33.16^{\prime}$ & $36^{\circ} 33.32^{\prime}$ & $4803-4818$ & EBS \\
\hline $110 \# 8$ & $64^{\circ} 58.95^{\prime}$ & $43^{\circ} 01.97^{\prime}$ & $4696-4698$ & EBS \\
\hline $133 \# 2$ & $62^{\circ} 46.95^{\prime}$ & $53^{\circ} 01.72^{\prime}$ & $1549-1579$ & EBS \\
\hline
\end{tabular}

Histology: The foraminiferans were transferred from the fixative ( $4 \%$ formalin buffered with disodiumtetraborate [often called borax]) to distilled water and were thereafter dehydrated through an alcohol series to absolute alcohol. They were then embedded in resin (Epon) and sectioned by the use of a microtome (Mikrotom HM $355 \mathrm{~S}$ from Microm). The slides were stained in $0.1 \%$ toluidine blue with $0.2 \%$ borax solution for 2 minutes, differentiated in absolute alcohol, and mounted under coverslips using the medium Gurr ${ }^{\circledR}$ XAM neutral medium improved white, from the company BDH Chemicals Ltd., Poole, UK. Five specimens of L. flavofusca gen. et sp. nov. and two of L. grisea gen. et sp. nov. were used for histological studies.

SEM: the foraminiferans were transferred from the fixative to distilled water and were thereafter dehydrated through an alcohol series to absolute alcohol. They were then dried by the use of an EMS 850 Critical Point Dryer, mounted on stubs using carbon tape, and in a few cases also celluloide-based glue, and coated by gold-palladium in an Edwards Sputter Coater S150B during 4.5 minutes resulting in a coating 670 Ångström thick. They were studied in a scanning electron microscope (CamScan MaXim 2040 S) at Institute of Astronomy and Physics, University of Aarhus, Denmark. Nine specimens of L. flavofusca gen. et sp. nov. and three of $L$. grisea gen. et sp. nov. were used for SEM studies. 
Molecular methods: a fragment of the SSU rRNA gene was amplified by PCR with the primer pair s14F3 (5'ACG CA(AC) GTG TGA AAC TTG) and sB (5' TGA TCC TTC TGC AGG TTC ACC TAC), and reamplified using nested primer s14F1 (5' AAG GGC ACC ACA AGA ACG C). The amplified PCR products were purified using High Pure PCR Purification Kit (Roche Diagnostics) and sequenced directly or after cloning. In the latter case, the purified products were ligated in the Topo Cloning vector (Invitro Gene), and cloned using ultracompetent cells XL2-Blue MRF' (Stratagene). Sequencing reactions were prepared using an ABI-PRISM Big Dye Terminator Cycle Sequencing Kit and analysed with an ABI-377 DNA sequencer or an ABI-PRISM 3100 (Applied Biosystems), all according to the manufacturer's instructions. The sequences were deposited in the EMBL/GenBank under accession numbers FM209499-209511.

Sequences were compared to 41 other foraminiferan sequences and manually aligned using the Seaview software (Galtier et al. 1996). Highly variable regions of the alignment were removed. The maximum likelihood tree was constructed with GTR + G + I model, using Phy_ML program (Guindon \& Gascuel 2003).

\section{Taxonomy}

\section{Foraminifera d'Orbigny, 1826 Saccamminidae Brady, 1884}

According to conventional, morphology-based taxonomic systems (Loeblich \& Tappan 1987; Sen Gupta 1999; Lee et al. 2000), the monothalamous foraminiferans are divided in taxa based on the test composition. Those with an organic test form the order Allogromiina while those with an agglutinating test form the order Textulariida. The textulariid superfamily Astrorhizacea is defined by an agglutinated test that is irregular, rounded, tubular or branching, nonseptate or with the interior only partially subdivided. It includes the family Saccamminidae in which the test is free or attached, globular or elongate; single or multiple, rounded or slitlike apertures are present. The subfamily Saccammininae Brady, 1884 commonly has a distinctive organic oral apparatus consisting of an 'inward projecting tube enclosing a gel-like capsule' (Loeblich \& Tappan 1987; Lee et al. 2000). However, the systematic division of higher taxa based on morphology has little support from molecular studies (Pawlowski et al. 2002). We therefore recognise the family Saccamminidae only in order to provide a systematic context for our new taxa that is consistent with previous studies.

\section{Leptammina gen. nov.}

Etymology: The first part of the name is derived from the Greek word leptos $(\lambda \varepsilon \pi \tau \circ \varsigma)$ meaning thin and refers to the thin test wall. The last part, -ammina, is a common ending of many generic names of agglutinating foraminiferans, particularly those with tests of sand grains, and is derived from the Greek word ammos $(\alpha \mu \mu \mathrm{s})$, meaning sand.

Type species: Leptammina flavofusca sp. nov.

Definition: Test free, monothalamous and more or less spherical, up to $2 \mathrm{~mm}$ diameter. Wall delicate, flexible, with inner organic layer overlain by fine, loosely agglutinated mineral grains. Single prominent circular aperture, which may protrude slightly from the test surface. Cell body with well-developed peduncular sheath.

Remarks: The two species described below look superficially different, particularly in terms of their colour. However, they are united by a number of test features, notably the wall structure, the presence of a peduncular sheath, and the size and form of the aperture. Moreover, our molecular analyses indicate that they are closely related (Fig. 6).

At least one globular, soft-walled monothalamous foraminiferan with a single aperture has been included in the genus Saccammina. Hedley (1962) placed his new species $S$. alba here, but with evident hesitation. He 
remarks - 'The present author has followed Le Calvez (1935) in placing a Foraminifer with a fragile, white shell in the genus Saccammina, the type species of which has a hard, brittle, ferruginous shell. If, in the future, sufficient becomes known about the various species of saccamminids to warrant a division into two genera, it seems likely that a basis for it may be found in the two shell types.' We agree that the differences between softwalled saccamminids in general and the type species Saccammina sphaerica Carpenter, 1869 are sufficient to justify the establishment of at least one new genus. The type species of the genus Saccammina is large, up to at least $4 \mathrm{~mm}$ diameter, with a rigid, fairly coarsely and firmly agglutinated wall. In these respects, it is unlike S. alba or the two delicate, soft-walled species described here. We establish the new genus Leptammina to accommodate our new species and $S$. alba. The last species, however, is included with some hesitation because of lack of molecular data.

Several other genera of soft-walled saccamminids have been described. Perhaps the most similar genus to Leptammina is Pilulinella (type species P. sphaerica Saidova, 1975). It is described by Loeblich and Tappan (1987) as being 'spherical', 1-2 mm in diameter with a single rounded terminal aperture and a wall composed of 'fine clay' particles on an organic base. The aperture in Pilulinella is reported to be a kind of double structure, although this could indicate the presence of a peduncular sheath. Unfortunately, not enough information is currently available about Pilulinella to determine how close it is to the new genus. However, the apparently greater size of the aperture may be one distinguishing feature. The diameter of the rim of the aperture is about one third of the test diameter in Pilulinella and about a fifth to a tenth of the test diameter in Leptammina.

Ovammina (type species O. opaca Dahlgren, 1962; synonym Dahlgrenia Lena, 1974) resembles Leptammina in having an agglutinated test wall made of minute mineral particles underlain by an organic layer. Both genera also have an entosolenian tube. It differs from Leptammina in being smaller (length130-700 $\mu \mathrm{m}$ ) and ovoid, egg-shaped or fusiform rather than rounded in general test shape There is also no evidence in the new genus for the ring of accessory apertures around the main aperture that develop in Ovammina during gametogenesis.

Psammophaga (type species P. simplora Arnold, 1982) resembles Leptammina in having an outer finely agglutinating test layer and an inner organic wall. Both genera also have an entosolenian tube. One obvious difference is that Psammophaga ingests large quantities of mineral particles (Arnold 1982), a feature never observed in Leptammina. The test also has a relatively much thicker inner organic layer than that of Leptammina.

Like Saccammina, the genus Pilulina (type species P. jeffreysii Carpenter, 1875) is a heterogeneous taxon in need of revision. The species $P$. jeffreysii is large, up to at least $4 \mathrm{~mm}$ diameter, with a fairly rigid test wall and an elongate slit-like aperture. Pilulina does not have any similarity to Leptammina. However, some species assigned to this genus differ from the type species so much that their placement is questionable. Pilulina ovata Cushman, 1910, described from the North Pacific Ocean, has an oval test with a very thin, finely agglutinated wall. However, it is much larger than Leptammina and has an irregularly shaped aperture. Another species, Pilulina argentea Höglund, 1947, resembles superficially the "silver saccamminid" of Pawlowski et al. $(2002,2005)$ so much that we earlier believed them to be identical. Höglund (1947) included this species in the genus Pilulina with some hesitation. He wrote "Rather than erect a new genus, I am referring this species to Pilulina, although neither the aperture nor the structure of the wall exactly coincides with any of the hitherto described species belonging to this genus". Molecular evidence (see below) suggests that one undescribed species with a reflective, silver-coloured test wall is closely related to Leptammina.

\section{Leptammina grisea gen. et sp. nov.}

(Figs 1-2)

Material: Polarstern Station 102\#11 (Agassiz trawl) 25 specimens; Station 102\#13 (Epibenthic sledge) 2 specimens; Station $110 \# 8$ (Epibenthic sledge) 1 specimen; Station $133 \# 2$ (Epibenthic sledge) 1 specimen. 

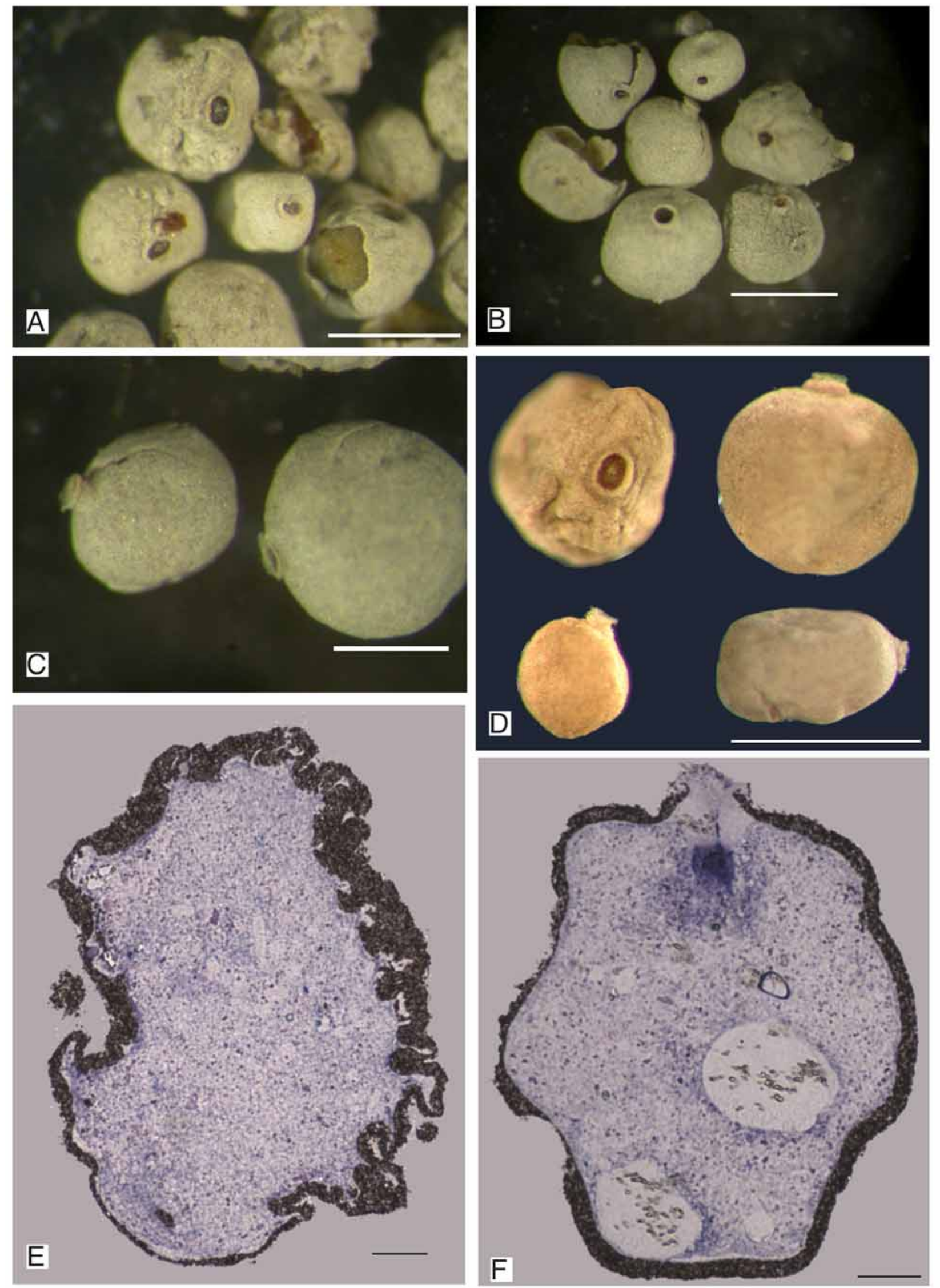

FIGURE 1. Leptammina grisea gen. et sp. nov., A-C are fresh, newly collected individuals and D are individuals fixed in formalin. E. Test wall wrinkles, probably artefacts during handling or fixation. F. Longitudinal section of entire individual with agglutinated test, inner organic lining, peduncular sheath, cytoplasm, foreign particles, and vacuoles. All individuals from Stn. 102\#11 AT. Scale bars: $\mathrm{A}-\mathrm{D}=1 \mathrm{~mm} ; \mathrm{E}-\mathrm{F}=100 \mu \mathrm{m}$. 

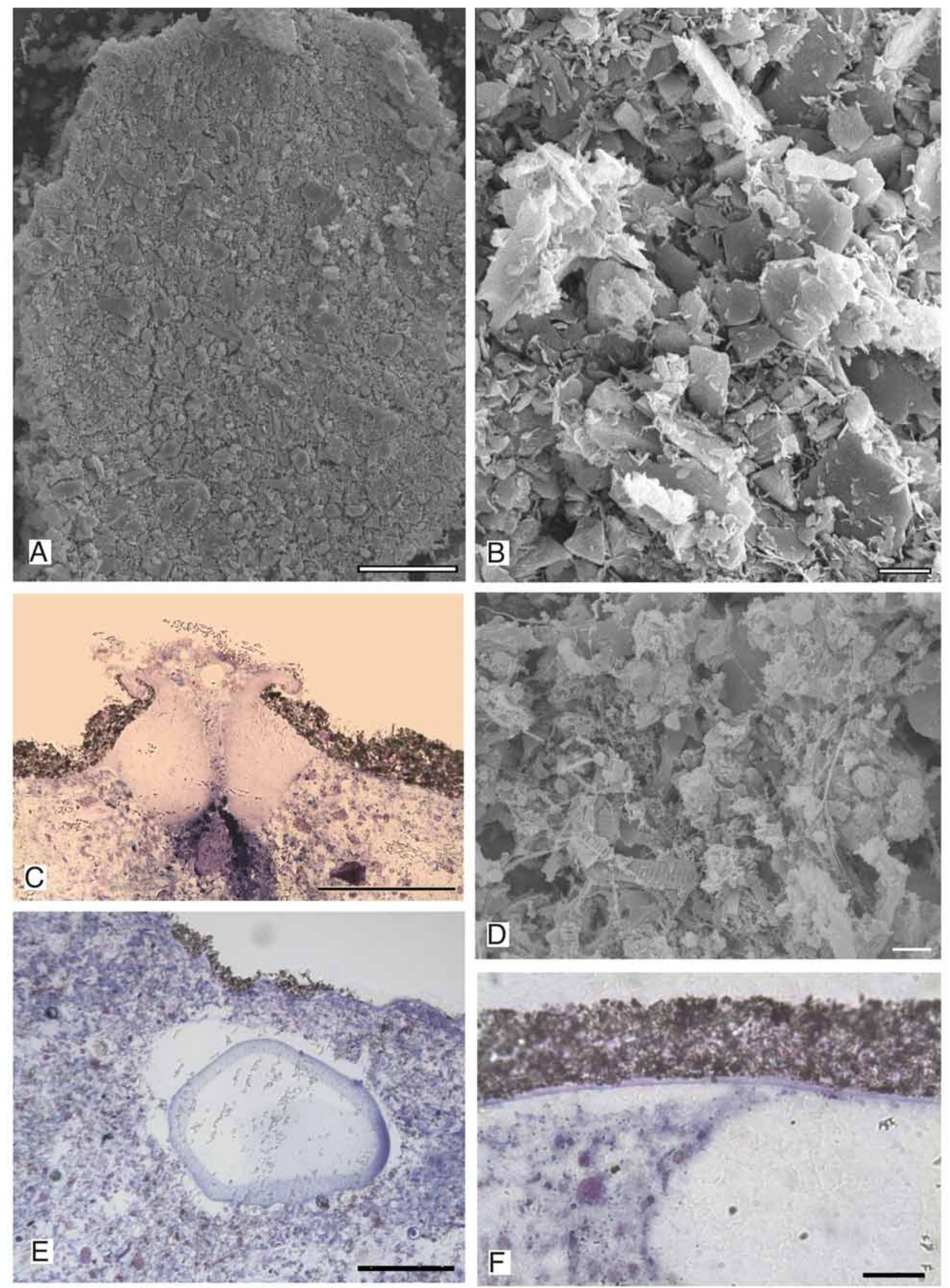

FIGURE 2. Leptammina grisea gen. et sp. nov., A + B. SEM photograph of agglutinated outer test wall. C. Aperture with peduncular sheath (stomostyle) projected by the cytoplasm along its longitudinal axis; the transition of the peduncular sheath into the inner organic lining is clearly visible at both sides. D. SEM photograph of a broken part of the cell showing pseudopodia (reticulopodia) embedding stercomata, mineral particles, and diatom frustules. E. Nucleus of the granular type with numerous nucleoli, most of the nuclear interior consists of a vacuole. F. Agglutinated lager, inner organic lining, cell content and vacuole. All individuals from Stn. 102\#11 AT. Scale bars: $A+F=20 \mu \mathrm{m} ; \mathrm{B}=2 \mu \mathrm{m} ; \mathrm{C}+\mathrm{E}=100 \mu \mathrm{m} ; \mathrm{D}=5 \mu \mathrm{m}$. 
Derivation of name: grisea is the Medieval Latinization of the French word gris, and means grey. It refers to the colour of the test.

Diagnosis. Approximately spherical species of Leptammina, up to $2 \mathrm{~mm}$ diameter, characterized by soft, delicate, finely agglutinated test, grayish or violet-grey in colour and opaque, with dull, non-reflective surface. Single, prominent circular aperture. Cell body dark greenish, with single nucleus. Peduncular sheath well developed.

Deposition of type material: The holotype from Station 102\#11 and paratypes from Stations 102\#11, 102\#13, 110\#8, and 133\#2 are deposited in the Forschungsinstitut Senckenberg, Frankfurt am Main, Germany, under reg. no. SMF XXVII 7537.

Description. General morphology. The test is free and a distinctive grey or violet-grey colour. Unfixed specimens are roughly spherical, occasionally more elongate, and often somewhat irregular in shape (Figs 1A-D). The diameter ranges from 620 to $1360 \mu \mathrm{m}$ (mean $0.91 \mathrm{~mm}$; median $0.91 \mathrm{~mm}$; $\mathrm{n}=24$ individuals). There is one round aperture on a short neck and surrounded by a thin raised collar.

Test wall. The wall is soft, delicate and easily detached. The surface has a dull, non-reflective appearance. It is smooth when viewed under the light microscope but slightly rough when viewed at higher magnifications $(1,000 \mathrm{X}-5,000 \mathrm{X})$ in the SEM. The wall includes a thin, outer agglutinated layer, up to $30 \mu \mathrm{m}$ thick, and an inner organic lining, $\sim 3 \mu \mathrm{m}$ thick (Figs 1E-F; $2 \mathrm{~F}$ ). The outer layer is composed of small mineral particles varying in size from $\sim 10 \mu \mathrm{m}$ maximum dimension to $1 \mu \mathrm{m}$ or less (Figs $2 \mathrm{~A}-\mathrm{B}$ ). Many of these particles are angular in shape.

Cell body. In fresh, newly collected individuals, the cell body is a dark green or brownish green and entirely fills the test (Fig. 1E-F). A distinct peduncular sheath (stomostyle) is located immediately inside the aperture and may extend into the apertural neck and cover the rim of the aperture (Fig. 2C). It is also continuous with the inner organic lining of the test wall. Light microscopic sections reveal one large nucleus, up to $240 \mu \mathrm{m}$ diameter, of the granular type with numerous nucleoli, located within an exonuclear vacuole. The center of the nucleus is occupied by a vacuole, up to $200 \mu \mathrm{m}$ wide (Fig. 2F). Large vacuoles are also visible within the cytoplasm of sectioned individuals. Pseudopodia were not observed, although a thin string of cytoplasm projects along the central axis of the peduncular sheath (Fig. 2C). However, in critical-point dried individuals studied by SEM, the cell body consists of a dense network of fine pseudopodia (reticulopodia) that incorporate stercomata, mineral particles, diatoms, and other foreign particles (Fig. 2D).

Remarks: Leptammina grisea gen. et sp. nov. closely resembles Saccammina alba in the general form and construction of the test. The main differences are that the test is larger (620 to $1360 \mu \mathrm{m}$ compared to a maximum size of $400 \mu \mathrm{m}$ in $S$. alba), the test wall is thicker, and the surface is greyish rather than white. It should also be noted that $S$. alba was described from an intertidal setting whereas the new species occurs at bathyal and abyssal depths. Leptammina grisea gen. et sp. nov. differs from Pilulina argentea in having a dull grey rather than reflective, silvery surface. See also "Remarks" under L. flavofusca gen. et sp. nov.

Distribution: Weddell Sea, central part at 4795, 4822, and $4698 \mathrm{~m}$ depth, northwestern part at $1580 \mathrm{~m}$ depth.

\section{Leptammina flavofusca gen. et sp. nov.}

(Figs 3-5)

Material. Polarstern station 102\#11 (Agassiz trawl) 125 specimens; Station 102\#13 (Epibenthic sledge) 199 specimens; Station 80\#9 (Epibenthic sledge) 11 specimens; Station 110\#8 (Epibenthic sledge) 50 specimens; Station $81 \# 9 * *$ (Agassiz trawl) 8 specimens.

Derivation of name: flavofusca is derived from the Latin words flavus, meaning yellow and fuscus, meaning brown, dusky or tawny. It refers to the colour of the test.

Diagnosis. Approximately spherical species of Leptammina, up to $1.2 \mathrm{~mm}$ in diameter, with test wall composed of very thin, finely agglutinated layer overlying inner organic lining. Single prominent circular 
aperture. Peduncular sheath well developed. Cell body brownish-yellow in colour, visible through semitransparent test wall, with single large nucleus.

Deposition of type material: The holotype from Station 102\#11 and paratypes, from Stations 102\#11, 102\#13, 80\#9, 110\#8, and 81\#9** are deposited in the Forschungsinstitut Senckenberg, Frankfurt am Main, Germany, under reg. no. SMF XXVII 7536.

Description. General morphology. The test is free and brownish-yellow in colour. Unfixed specimens have a very even, approximately spherical shape (Fig. 3) and range in diameter from 345 to $1210 \mu \mathrm{m}$ (mean=690 $\mu \mathrm{m}$; median=702 $\mu \mathrm{m} ; \mathrm{n}=180$ ). When dried for examination in the SEM, some distortion of the shape usually occurs. There is a single circular aperture surrounded by a thin collar at the end of a very short neck (Figs 4B-C).

Test wall. The wall is $<10 \mu \mathrm{m}$ thick, semitransparent, and comprises a very thin and delicate outer agglutinated layer and an inner organic lining (Fig. 5A-D). The surface is smooth, dull and non-reflective. The agglutinated particles that comprise the outer layer are $<10 \mu \mathrm{m}$ in size and generally angular, with larger particles embedded in a matrix of finer particles, one to a few $\mu \mathrm{m}$ in size (Fig. 4E-F).

Cell body. The brownish-yellow cell body completely fills the test interior but may shrink after fixation. A distinct organic peduncular sheath (stomostyle) is located immediately inside the aperture (Fig. 5B); it may extend into the apertural neck and onto the rim of the aperture. A projection from the peduncular sheath forms the inner organic lining along the entire inside of the test. Some vacuoles are visible in sectioned individuals. There is one large nucleus, up to $165 \mu \mathrm{m}$ diameter, of the granular type, with few scattered nucleoli along its periphery (Fig. 5A). The nucleus is a folded or approximately round in shape and is located within an exonuclear vacuole. A vacuole, up to $100 \mu \mathrm{m}$ wide; is sometimes located in the center of the nucleus. Pseudopodia have not been observed but a thin string of cytoplasm projects through the centre of the peduncular sheath, along its central axis. However, examination of the cell body of critical-point dried individuals by SEM reveals a dense network of cytoplasm organized like fine pseudopodia (reticulopodia), in which are embedded stercomata, mineral particles, and other foreign inclusions (Fig. 4D).

Remarks: Leptammina flavofusca gen. et sp. nov. differs from L. grisea gen. et sp. nov. in the smoother and more regular shape of the test, which is yellowish-brown rather than greyish in colour. Both species were most abundant at Station 102. It might be argued that the species look different merely due to the available inorganic particles available at any given site but the fact that they co-occurred argues against this possibility. Leptammina flavofusca gen. et sp. nov. is also clearly distinguished from Saccammina alba and Pilulina argentea by the distinctive colour of the test.

Distribution: Weddell Sea, central part at $4795 \mathrm{~m}$ depth; off Kapp Norvegia at 3138 and $4385 \mathrm{~m}$ depth.

Molecular characterization. Seven sequences of $L$. flavofusca gen. et sp. nov. and six sequences of $L$. grisea gen. et sp. nov. were obtained from four and three isolates of each species, respectively. No particular structural features (introns, insertions) were observed. The sequenced fragments ranged from 1110 to 1112 nucleotides in L. grisea gen. et sp. nov. and from 1132 to 1137 nucleotides in L. flavofusca gen. et sp. nov. The GC content was 39.0-39.5\% in L. flavofusca gen. et sp. nov. and 40.8-41.2\% in L. grisea gen. et sp. nov. The sequences of both species differed by 15.4 to $16.2 \%$, while the divergence within each species was below 1 $\%$.

Thirteen sequences of Leptammina gen. nov. were aligned to 41 sequences including the major groups of monothalamous foraminiferans (Fig. 6). Maximum likelihood phylogenetic analysis showed that both species group together with an undescribed Antarctic shallow water species, called "silver saccamminid" (Gooday et al. 1996) in a very strongly supported clade (100\%). The relationships between the two Leptammina species were relatively weakly supported (79 \%) and in some trees the "silver saccammminid A26" branched among them. The three species clustered together with several other monothalamous species of the lineage C, a heterogeneous assemblage including, among others, genera such as Hippocrepinella Heron-Allen \& Earland, 1932, Rhizammina Brady, 1879, Toxisarcon Cedhagen \& Pawlowski, 2002, Gloiogullmia Nyholm, 1974, Cylindrogullmia Nyholm, 1974, Bathyallogromia Gooday, Holzmann, Guiard, Cornelius \& Pawlowski, 2004, as well as the Xenophyophorea (Aranda da Silva, unpublished). 

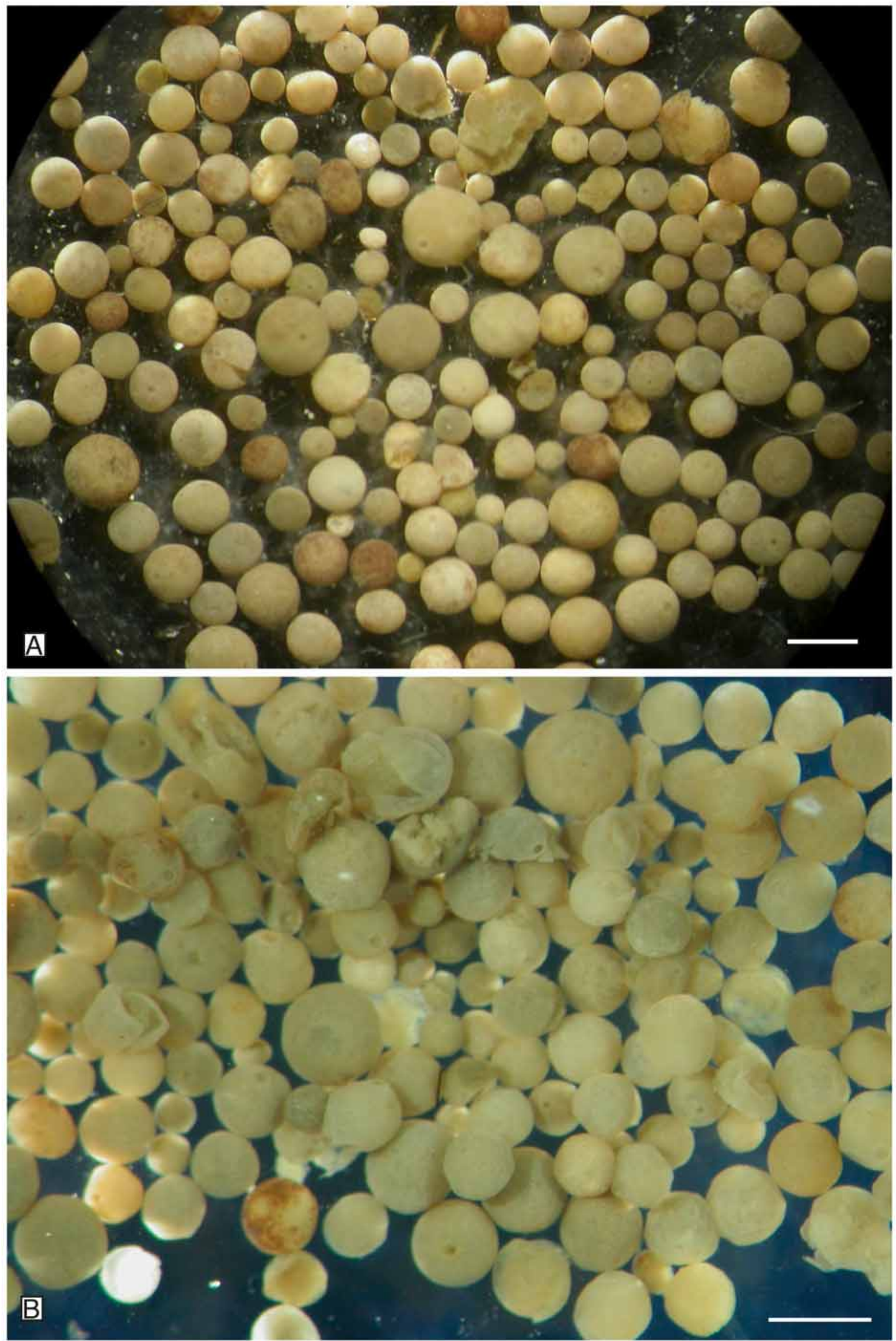

FIGURE 3. Leptammina flavofusca gen. et sp. nov. Assemblage of individuals from Stn.102\#13 EBS. A. Fresh, newly collected, and probably alive individuals. B. The same individuals after fixation in formalin. Scale bars $=1 \mathrm{~mm}$. 

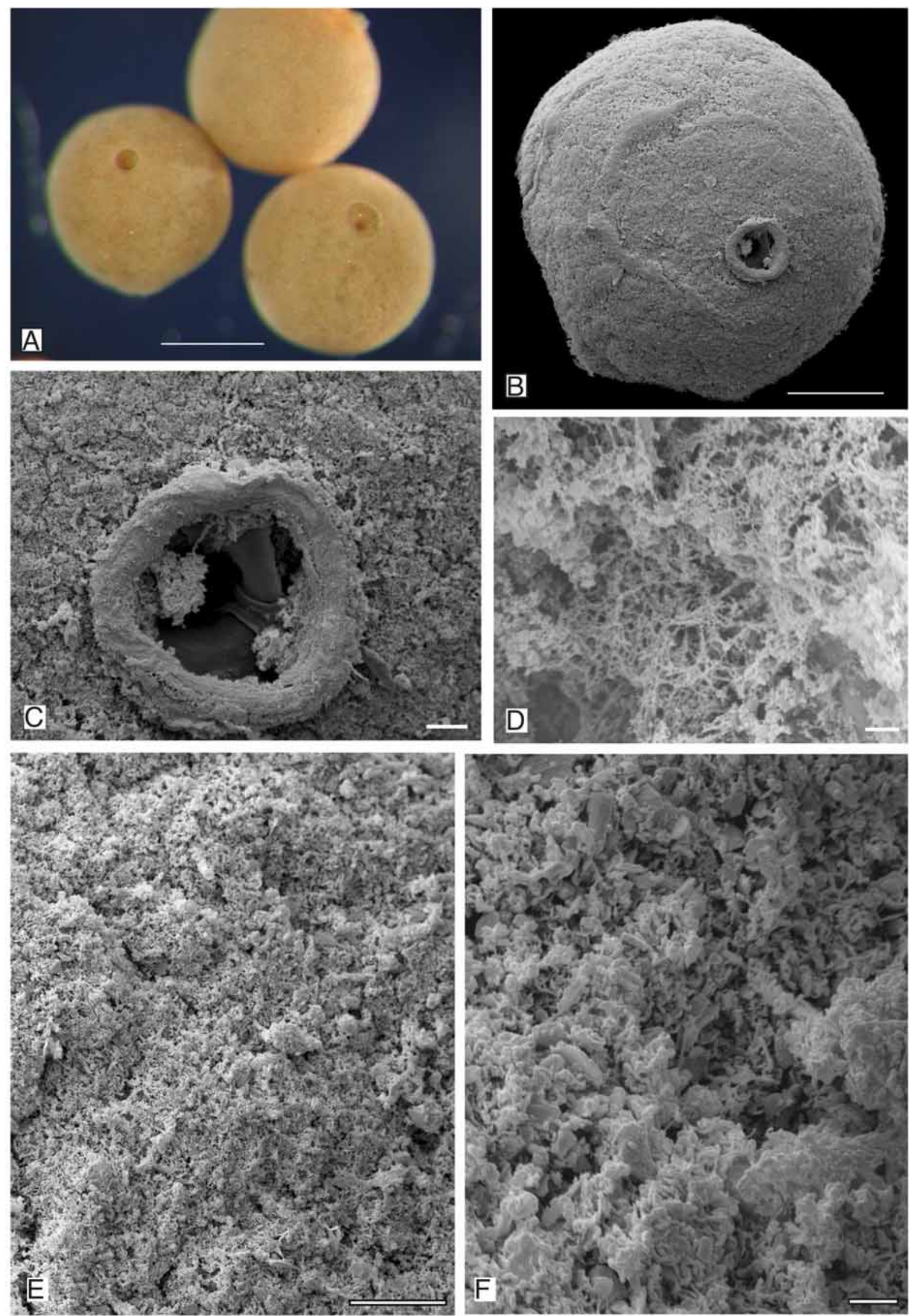

FIGURE 4. Leptammina flavofusca gen. et sp. nov. A. Fresh, newly collected, and probably alive individuals, two of them with the aperture directed upwards which makes it possible to see that the peduncular sheath is funnel shaped. B. SEM photograph of entire individual. C. SEM photograph of aperture. D. SEM photograph of broken surface of the cell showing that it is built up by a cytoplasmic network of reticulopodia. E+F. SEM photographs of test surface. Scale bars: A=500 $\mu \mathrm{m}, \mathrm{B}+\mathrm{E}=200 \mu \mathrm{m}, \mathrm{C}=20 \mu \mathrm{m}, \mathrm{D}+\mathrm{F}=2$ $\mu \mathrm{m}$. All individuals are from Stn.102\#13 EBS. 

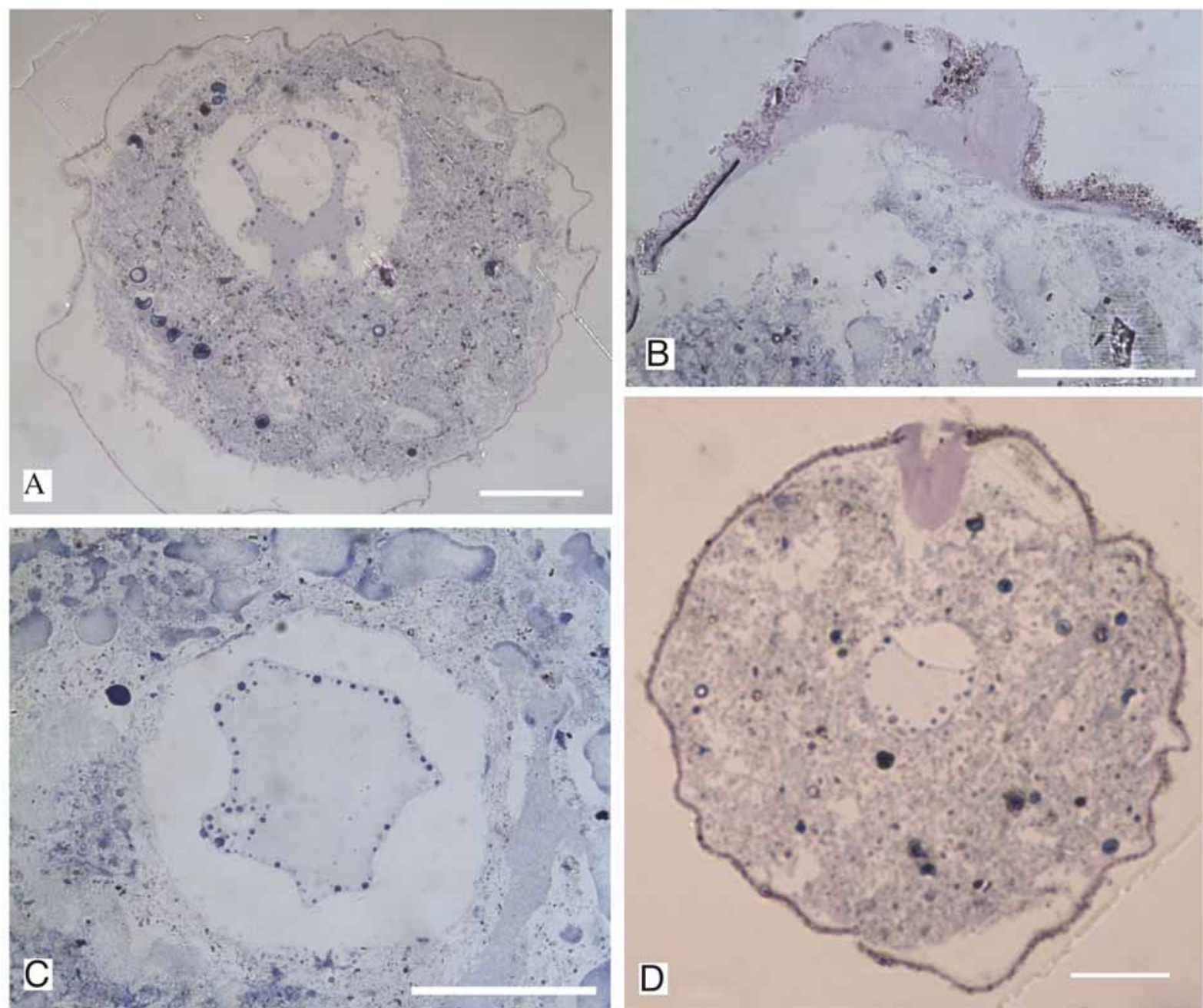

FIGURE 5. Leptammina flavofusca gen. et sp. nov. A. Section through entire individual with nucleus, nucleoli, nuclear vacuole and exonuclear vacuole. B. Longitudinal section of aperture with peduncular sheath, agglutinated test material and inner organic lining. C. Section through nucleus and exonuclear vacuole, but without nuclear vacuole. D. Longitudinal section of Scale bars $=100 \mu \mathrm{m}$.

\section{Discussion}

Soft-walled saccamminids, with flexible agglutinating test wall, are a consistent component of deep-sea foraminiferal assemblages (Gooday 2002). They are reported from the bathyal and abyssal northeast Atlantic (Gooday 1986, 1996; Gooday \& Hughes 2002), the North and central Pacific (Gooday et al. 2001, 2004b; Nozawa et al. 2006), and the Arabian Sea (Gooday et al. 2000). Cornelius and Gooday (2004) found that softwalled monothalamous foraminifera (saccamminids and organic walled allogromiids) represent an increasing proportion of the 'live' (Rose Bengal stained) foraminiferal assemblage with increasing water depth in the Weddell Sea. Deep-sea saccamminids are typically diverse, and represented by more species than the organicwalled allogromiids. The records cited above were all based on relatively small core samples collected with a multiple corer and processed using a sieve with a mesh size of $63 \mu \mathrm{m}$ or $32 \mu \mathrm{m}$. The saccamminids recovered from these fine sieve fractions are small, usually $<150 \mu \mathrm{m}$ and often $<100 \mu \mathrm{m}$ in size, and invariably undescribed. Our present study reveals that larger deep-sea saccamminids $(>1 \mathrm{~mm})$ are present in epibenthic sledge (EBS) samples that concentrate organisms from much larger areas of seafloor than are sampled by cores. The EBS samples obtained during the ANDEEP III campaign yielded at least five additional undescribed species of soft-walled saccamminids. These are not described here because insufficient material in a suitable state of preservation was available. However, together with the new species, they emphasise how little is known about the diversity and systematics of soft-walled, monothalamous foraminifera in the deep sea. 
Neither Leptammina grisea gen. et sp. nov. nor L. flavofusca gen. et sp. nov. are recorded from outside the Weddell Sea. For example, they are not present in EBS samples collected on the continental slope and rise under the NW African upwelling area (Gooday unpublished observations), or at deeper-water sites near Svalbard (Gooday et al. 2005). Whether these species are more widely distributed remains an open question at present. Undersampling of deep-ocean communities means that our knowledge of the biogeography and bathymtric distribution of deep-sea organisms is often rudimentary, particularly for smaller size classes. It is interesting to note, however, that one of our new species, Leptammina grisea gen. et sp. nov., is most similar morphologically to an intertidal species, Saccammina alba.

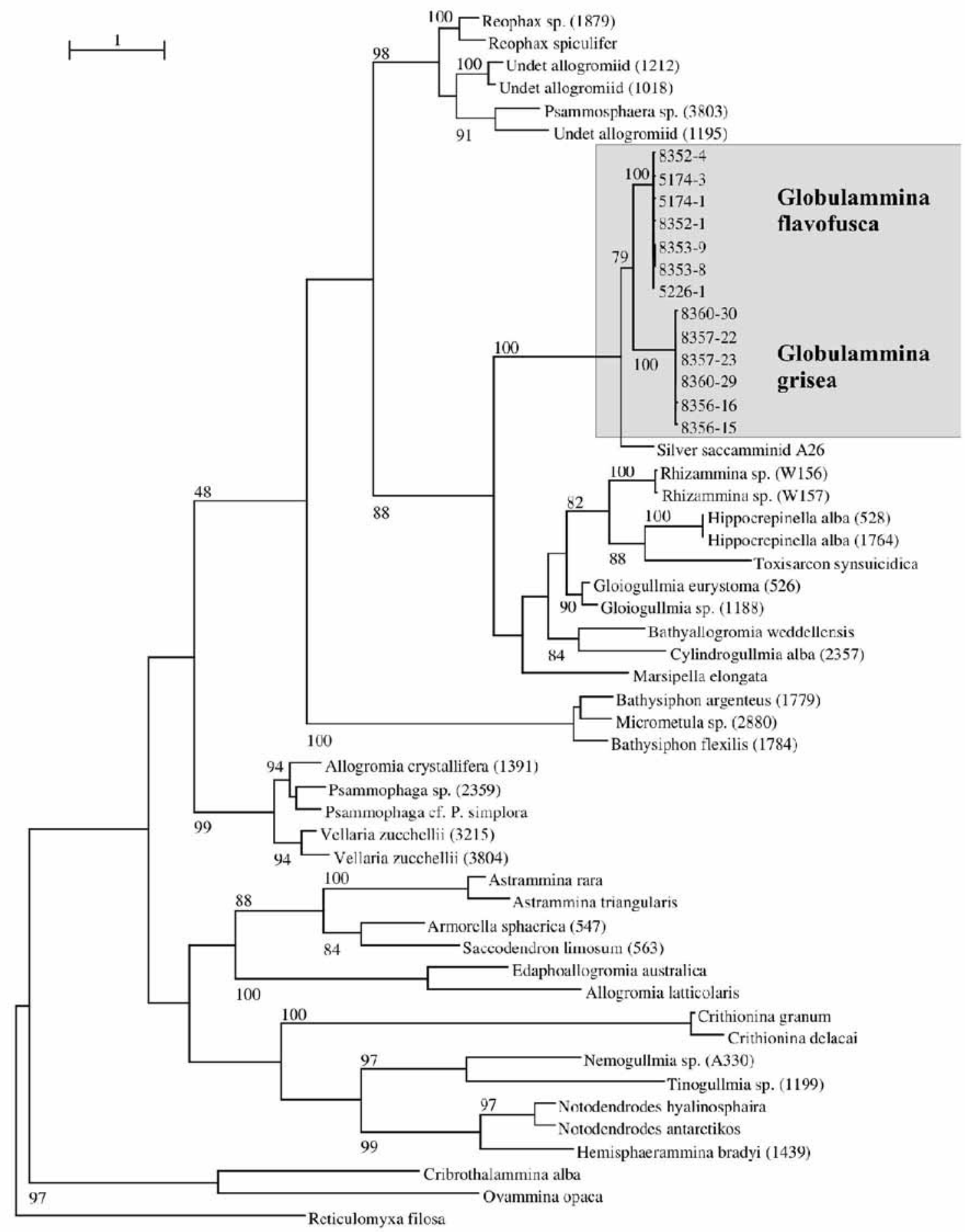

FIGURE 6. Phylogenetic position of Leptammina gen. nov. inferred from partial SSU rDNA sequences using maximum likelihood method. Numbers at internal nodes correspond to bootstrap values higher than $75 \%$. 


\section{Acknowledgments}

We thank Prof. Angelika Brandt for inviting two of us (AJG, TC) to participate in the ANDEEP III expedition and making available material from the epibenthic sledge and Agassiz trawl, Prof. Eberhard Fahrbach for his efficient running of the Polarstern ANT XXII/3 cruise, and the Captain, officers and crew of the RV Polarstern for their assistance during the cruise. We also thank Mrs. Susanne Petersen for help with histological and SEM work, and Jackie Guiard for cloning and sequencing. This study was supported by the Danish Research Agency (Grant no. 95091435 to TC), the UK Natural Environment Research Council (Grant no. NER/B/S/2001/00336 to AJG), and the Swiss National Science Foundation (Grant no. 3100A0-112645 to JP). This is ANDEEP publication no 110. This publication also contributes to the CoML field project CeDAMar.

\section{References}

Arnold, Z. (1982) Psammophaga simplora n. gen., n. sp., a polygenomic Californian saccamminid. Journal of Foraminiferal Research 12, 72-78.

Brady, H.B. (1879) Notes on some of the Reticularian Rhizopoda of the "Challenger" Expedition. Part 1. On new or little known arenaceous types. Quarterly Journal of Microscopical Science, new ser. 19, $20-63$.

Brady, H.B. (1884) Report on the foraminifera dredged by H. M. S. Challenger, during the years 1873-1876, in Report on the Scientific Results of the Voyage of the H. M. S. Challenger during the years 1873-1876, Zoology, v. 9, xxi+813 pp , 1 map, 115 pls.

Brandt, A., Brix, S., Brökeland, W., Cedhagen, T., Choudhury, M., Cornelius, N., Danis, B., De Mesel, I., Diaz, R.J., Gillan, D.C., Ebbe, B., Howe, J., Janussen, D., Kaiser, S., Linse, K., Malyutina, M., Brandão, S.N., Pawlowski, J., Raupach, M., Vanreusel, A. \& Gooday, A.J. (2007) The Southern Ocean deep sea: first insights into biodiversity and biogeography. Nature 447, 307-311.

Carpenter, W.B. (1869) On the rhizopodal fauna of the deep sea. Proceedings of the Royal Society of London 18, 59-62.

Carpenter, W.B. (1875) The Microscope and Its Revelations, 5th ed., J. \& A. Churchill, London, xxxii+848 pp., 25 pls.

Cedhagen, T. \& Pawlowski, J. (2002) Toxisarcon synsuicidica n. gen., n. sp., a large monothalamous foraminiferan from the west coast of Sweden. Journal of Foraminiferal Research 32, 351-357.

Cornelius, N. \& Gooday, A.J. (2004) "Live" (stained) deep-sea benthic foraminiferans in the western Weddell Sea: trends in abundance, diversity and taxonomic composition along a depth transect. Deep-Sea Research II 51, 1571-1602.

Cushman, J.A. (1910) A monograph of the foraminifera of the North Pacific Ocean. Pt. 1. Astrorhizidae and Lituolidae. Bulletin of the United States National Museum 71(1), 1-134.

Dahlgren, L. (1962) A new monothalamous foraminifer, Ovammina opaca n.gen., n.sp., belonging to the family Saccamminidae. Zoologiska Bidrag från Uppsala 33, 197-200 + pl.

Gooday, A.J. (1986) Soft-shelled Foraminifera in meiofaunal samples from the bathyal northeast Atlantic. Sarsia, 71, $275-287$.

Gooday, A.J. (1996) Epifaunal and shallow infaunal foraminiferal communities at three abyssal NE Atlantic sites subject to differing phytodetritus input regimes. Deep-Sea Research I, 43, 1395-1421.

Gooday, A.J.. (2002) Organic-walled allogromiids: aspects of their occurrence, diversity and ecology in marine habitats. Journal of Foraminiferal Research, 32, 384-399.

Gooday, A.J., Hughes, J.A., 2002. Foraminifera associated with phytodetritus deposits at a bathyal site in the northern Rockall Trough (NE Atlantic): seasonal contrasts and a comparison of stained and dead assemblages. Marine Micropaleontology, 46, 83-110.

Gooday, A.J. \& Pawlowski, J. (2004) Conqueria laevis gen. and sp. nov., a new soft-walled monothalamous foraminiferan from the deep Weddell Sea. Journal of the Marine Biological Association of the United Kingdom 84, 919-924.

Gooday, A.J., Bernhard, J.M., Levin, L.A. \& Suhr. S.B., (2000) Foraminifera in the Arabian Sea oxygen minimum zone and other oxygen deficient settings: taxonomic composition, diversity, and relation to metazoan faunas. Deep-Sea Research II, 47, 25-54.

Gooday, A.J., Bowser, S.S. \& Bernhard, J.M. (1996) Benthic foraminiferal assemblages in Explorer's Cove, Antarctica: a shallow water site with deep sea characteristics. Progress in Oceanography, 37, 219-267.

Gooday, A.J., Bowser, S.S., Cedhagen, T., Hald, M., Korsun, S. \& Pawlowski, J. (2005) Soft-walled monothalamous foraminifera and gromids from western Svalbard fjords: a preliminary report. Marine Biology Research 1, 290-312.

Gooday, A.J., Cedhagen, T. \& Cornelius, N. (2006) Diversity and biogeography of deep-sea benthic foraminifera - a 
combined molecular and morphological approach. Sonderforschungsbereich für Polarforschung. Pp. 89-94.

Gooday, A.J., Cedhagen, T., Kamenskaya, O.E. \& Cornelius, N. (2007a) The biodiversity and biogeography of komokiaceans and other enigmatic foraminiferan-like protists in the bathyal and abyssal Southern Ocean. Deep-Sea Research Part II, 54, 1691-1719.

Gooday, A.J., Holzmann, M., Guiard, J., Cornelius, N. \& Pawlowski, J. (2004a) A new foraminiferan from 1000 to 6300 $\mathrm{m}$ water depth in the Weddell Sea: morphological and molecular characterisation. Deep-Sea Research II 51, 1603-1616.

Gooday, A.J., Hori, S., Todo, Y., Okamoto, T., Kitazato, H., Sabbatini, A. (2004b) Soft-walled, monothalamous benthic foraminiferans in the Pacific, Indian and Atlantic Oceans: aspects of biodiversity and biogeography. Deep-Sea Research I, 51, 33-53

Gooday, A.J., Kamenskaya, O.E. \& Cedhagen, T. (2007b) New and little-known Komokiacea (Foraminifera) from the Weddell Sea and adjacent areas of the Southern Ocean. Zoological Journal of the Linnean Society 151, $219-251$.

Gooday, A.J., Kitazato, H., Hori, S., Okamoto, T. (2001) Monothalamous soft-shelled foraminifera at an abyssal site in the North Pacific: a preliminary report. Journal of Oceanography, 57, 377-384.

Guindon, S. \& Gascuel, O., 2003. A simple, fast, and accurate algorithm to estimate large phylogenies by maximum likelihood. Systematic Biology 52, 696-704.

Hedley, R.H. (1962) The significance of an "inner chitinous lining" in saccamminid organization with special reference to a new species of Saccammina (Foraminifera) from New Zealand. New Zealand Journal of Science 5, 375-389.

Heron-Allen, E. \& Earland, A. (1932) Some new foraminifera from the South Atlantic: IV. Four new genera from South Georgia. Journal of the Royal Microscopical Society of London, ser. 3, 52, 253-261.

Höglund, H. (1947) Foraminifera in the Gullmar fjord and the Skagerak. Zoologiska Bidrag från Uppsala 26, 1-328 + 32 pls.

Lee, J.J., Pawlowski, J., Debenay, J.-P., Whittaker, J., Banner, F., Gooday, A.J., Teldal, O.S., Haynes, J. \& Faber, W.W. (2000) Phylum Granuloreticulosa Lee, 1990. In: Lee, J.J., Leedale, G.F. \& Bradbury, P. (Eds.). An Illustrated Guide to the Protozoa (Second edition). Society of Protozoologists. Pp, 872-951.

Lena, H. (1974) Dahlgrenia patagoniensis gen. nov., sp. nov. (Foraminifera, Saccaminidae). Physis, Buenos Aires (Sect. A) 33(86), 9-16.

Lena, H. and D. Haman (1980). Dahlgreniella nom. nov. for the genus Dahlgrenia Lena (Foraminifera, Saccamminidae). Revista Española de Micropaleontología 12(2), 178.

Loeblich, A.R. \& Tappan, H. (1987) Foraminiferal Genera and their Classification. Van Nostrand Reinhold Company, New York, 2 vols, 970 pp. +847 pls.

Mikhalevich, V.I. (2004) The general aspects of the distribution of Antarctic foraminifera. Micropaleontology, 50, 179-194.

Nozawa, F., Kitazato, H. Tsuchiya, M., Gooday, A.J., 2006. 'Live' benthic foraminifera at an abyssal site in the equatorial Pacific nodule province: abundance, diversity and taxonomic composition. Deep-Sea Research I. 53, $1406-1422$.

Nyholm, K.-G. (1974) New monothalamous foraminifera. Zoon 2, 117-122.

Pawlowski, J., Holzmann, M., Berney, C., Fahrni, J., Cedhagen, T. \& Bowser, S.S. (2002) Phylogeny of allogromiid Foraminifera inferred from SSU rRNA gene sequences. Journal of Foraminiferal Research 32(4), 334-343.

Pawlowski, J., Holzmann, M., Berney, C., Fahrni, J., Gooday, A.J., Cedhagen, T. Habura, A. \& Bowser, S.S. (2003) The evolution of early Foraminifera. Proceedings of the National Academy of Sciences (PNAS) 100(20), 11494-11498.

Pawlowski, J., Fahrni, J.F., Guiard, J., Conlan, K., Hardecker, J., Habura, A. \& Bowser, S.S. (2005) Allogromiid foraminifera and gromiids from under the Ross Ice Shelf: morphological and molecular diversity. Polar Biology 28(7), 514-522.

Pawlowski, J., Majewski, W., Longet, D., Guiard, J., Cedhagen, T., Gooday, A.J., Korsun, S., Habura, A.A. \& Bowser, S.S. (2008) Genetic differentiation between Arctic and Antarctic monothalamous foraminifera. Polar Biology, 31, 1205-1216.

Sabbattini, A., Pawlowski, J., Gooday, A.J., Piraino, S., Bowser, S.S., Morigi, C. \& Negri, A. (2004) Vellaria zuccellii sp. nov. a new monothalamous foraminifer from Terra Nova Bay, Antarctica. Antarctic Science 16(3), 307-312.

Saidova, Kh.M. (1975) Bentosnye Foraminifery Tikhogo Okeana. Institut Okeanologii P.P. Shirshova, Akademiya Nauk SSSR, Moscow, 3 vols, 875 pp.

Sen Gupta, B.K. (1999) Systematics of modern Foraminifera. In: Sen Gupta, B.K. (Ed.). Modern Foraminifera. Kluwer Academic Publishers, Norwell MA, pp. 403-422. 